\title{
Ergenlerde Özerkliğin Yordayıcısı Olarak Bağlanma Stilleri ve Proaktif Kişilik Yapılarının İncelenmesi ${ }^{1}$
}

\author{
Prof. Dr. Recep KOÇAK* \\ Gaziosmanpaşa Üniversitesi, Eğitim Fakültesi, Tokat / Türkiye
}

Uzm. Psk. Dan. Hatice KARASU

Millî Eğitim Bakanlığı, Ankara / Türkiye

\section{$\ddot{\mathbf{O z}}$}

$\mathrm{Bu}$ çalışmada, ergenlerde özerkliğin yordayıcısı olarak bağlanma stilleri ve proaktif kişilik yapılarının ve ayrıca demografik özelliklere bağlı olarak öğrencilerin özerklik, bağlanma stilleri ve proaktif kişilik yapılarında anlamlı farklılaşma olup olmadığının incelenmesi amaçlanmıştır. Araştırma ilişkisel tarama modelinde bir çalışma olup, 2011-2012 eğitim öğretim yılında Ankara'da çeşitli liselerde öğrenim gören 249 kız, 174 erkek toplam 423 öğrenciden oluşan çalışma grubu ile yürütülmüştür. Araştırmada kullanılan veri toplama araçları; Musaağaoğlu (2004) tarafindan Türkçeye

\footnotetext{
${ }^{1}$ Bu çalışma birinci yazarın danışmanlığında ikinci yazarın yüksek lisans tez çalışmasından üretilmiş olup, 13. Ulusal Psikolojik Danışma ve Rehberlik Kongresinde sözlü bildiri olarak sunulmuştur.

* Sorumlu Yazar.

Tel: +905454882401

E-posta: srkocak05@gmail.com

(C) 2016 Kalem Eğitim ve Sağlık Hizmetleri Vakfı. Bütün Hakları Saklıdır.

ISSN: 2146-5606
} 
uyarlaması yapılan Ergen Özerklik Ölçeğidir. (The Adolescent Autonomy Scale) Orijinali ise Noom, Dekovici-Meeus (2001), tarafından 12-18 yaşları arasındaki ergenlerin özerkliğe ilişkin algılarını ölçmek amacıyla geliştirilmiştir. İkinci olarak bağlanma stillerini ölçmek için Sümer ve Güngör (1999), tarafından Türkçeye uyarlaması yapılan İlişki Ölçekleri Anketidir (Relationship Scales Questionnaire). Ölçek Bartholomew ve Horowitz (1991) tarafından geliştirilmiştir. Son olarak Şahin (2006), tarafından Türkçeye uyarlanan Proaktif Başa Çıkma Envanteri (Proactive Coping Inventory)'dir. Ayrıca araştırmacı tarafindan geliştirilen kişisel bilgi formu kullanılmıştır. Yapılan analizler sonucunda özerklik, bağlanma stilleri ve proaktif başa çıkma becerileri arasında anlamlı ilişkinin olduğu tespit edilmiştir $\left(\mathrm{r}=0.46, \mathrm{r}^{2}=0.08\right.$, $p<.01$ ). Analizler sonucunda proaktif başa çıkma boyutunun aşamalı regresyon analizine birinci merhalede girerek özerkliğin \%18.7 ile anlamlı yordayıcısı olduğu ve güvenli bağlanma boyutunun da \%1.3 ile onu takip ettiği tespit edilmiştir. Özerklikle bağlanma stilleri ve proaktif kişilik yapısı alt boyutları için korelasyon katsayıları incelendiğinde ise güvenli bağlanma ve proaktif başa çıkma alt boyutlarının birbiriyle pozitif yönde bir ilişkisinin olduğu, saplantılı bağlanma ve kaçınma başa çıkma alt boyutlarının negatif yönde bir ilişki içinde olduğu tespit edilmiştir.

Anahtar Kelimeler: Özerklik; Bağlanma stilleri; Proaktif kişilik; Ergenlik.

\title{
Investigation of Attachment Styles and Proactive Personality Structures as Predictors of Autonomy Among Adolescents
}

\begin{abstract}
In this study, it was aimed to investigate attachment styles and proactive personality structures as predictors of autonomy among adolescents, and to investigate whether or not there was a significant difference among the students' autonomy, attachment styles and proactive personality structures by their demographic variables. This research used a relational screening model. The participants of the study was composed of 249 female and 174 male students attending various public high schools in Ankara During 2011-2012 academic year. The first instrument was the Adolescent Autonomy Scale which was developed by Noom, Dekovic and Meus (2001) to assess the adolescents' perception of autonomy between the ages of 12-18. The second was the
\end{abstract}


Relationship Scales Questionnaire which was developed by Bartholomew and Horowitz (1991). The third was the Proactive Coping Inventory inorder to assess proactive personality structures. The last was a personal information form. Result of the study showed that there was a statistically significant relationship among the sub-dimensions of autonomy, attachment styles and proactive coping skills ( $\mathrm{r}=0.46$, $\left.\mathrm{r}^{2}=0.08, p<.01\right)$. It was also found that the dimension of proactive coping was a significant predictor of autonomy with the percentage of 18.7 by entering at the first stage of the stepwise regression analysis. It was followed by the dimension of safe commitment with a percentage of 1.3. According to correlation coefficients analyses showed that there was a positive relationship between safe attachment and proactive coping sub-dimensions, and a negative relationship between obsessive attachment and avoidant coping sub-dimensions.

Keywords: Autonomy; Attachment styles; Proactive personality structures; Adolescent.

\section{Extended Summary}

\section{Purpose}

Autonomy, attachment styles and proactive personality structures are important processes in development of personality. Autonomy, attachment styles and proactive personality structures are important for an individual to gain a place in society after growing apart the family environment. When the relevant literature was investigated, no study investigating attachment styles, autonomy and proactive personal structures together was encountered. Therefore, it was aimed to contribute to the field by investigating attachment styles, autonomy and proactive personal structures in terms of some variables through this study. There are a limited number of relevant studies in our country, and the subject should be considered in high school programs. Therefore, this study can contribute to the development of students. The findings that will be obtained after investigating attachment styles and 
proactive personality structures as predictors of autonomy are thought to be beneficial for families and school administrations to prevent some issues such as parental conflicts, drug addiction, suicide, sexual abuse and undisciplined behaviors.

The main aim of this study was to investigate attachment styles and proactive personality structures as predictors of autonomy. Another aim of this study was to investigate autonomy, attachment styles and proactive personality structures in terms of gender, number of siblings, order of birth, perceived socio-economic status and the settlement type longest lived.

\section{Method}

This study was designed as a corelational screening model which investigated whether or not a significant relationship exist between autonomy, attachment styles and proactive personality structures and examined the differences in terms of demographic variables. The study was conducted with 2 Anatolian High Schools, 3 Vocational High Schools and 2 General High Schools in Ankara. The participants were composed of a total of 423 students, 249 of whom were female and 174 were male. The data collection tools were conducted by one of the authors. The data of the study were collected through four different tools. "Personal Information Form" was developed by the researchers to collect socio-demographic variables. The autonomous development of the students was measured using "Adolescent Autonomy Scale" which was developed by Noom, Dekovic and Meeus (2001) and adapted into Turkish by Musaağaoğlu (2004). The attachment styles of 
the adolescents were determined using "Relation Scales Questionnaire" which was developed by Bartholomew and Horowitz (1991) and adapted into Turkish by Sümer and Güngör (1999). Lastly, "Proactive Coping Inventory" which was developed by Greenglass, Schwarzer, Jakubiec, Fiksenbaum and Taubert (1999) and adapted into Turkish by Şahin (2006) was used. Independent samples t-test, One-way ANOVA and Multiple Regression analyses were used.

\section{Results}

Autonomy, attachment styles and proactive personality structures were compared in terms of gender through t-test. The autonomy development demonstrated no significant difference in terms of gender. The male students significantly had higher scores in secure attachment and preoccupied attachment while female students had significantly higher scores in fearful attachment. It was determined that the female students had higher proactive coping levels compared to male students. The female students especially had higher scores in proactive, reactive, strategic planning and emotional support pursuit. The findings showed that autonomy, attachment styles and proactive personality structures did not differ significantly in terms of the number of siblings. Similarly, these variables did not differ in terms of the order of birth. As for the perceived socio-economic status, although there were differences in students' autonomy and proactive personality structure scores between lower group and higher group, these differences were not statistically significant. However, more students had secure attachment type as the economic status increased while other attachment types yielded no 
significant difference. The autonomy development and proactive personality structures did not differ in terms of the settlement type longest lived while the secure attachment dimension scores significantly differed in terms of the aforementioned variable. Multiple regression analyze was conducted to answer the question "do the attachment styles and proactive personality structures significantly predict the adolescents' autonomy?" Students' attachment styles and proactive personality structures were determined to be significant predictors of autonomy. Moreover, proactive coping dimension of proactive coping inventory and secure attachment dimension of attachment styles were found to be significant predictors of autonomy. Preoccupied dimension of attachment styles and avoidance dimension of proactive coping structures were entered the regression in the fourth model, and were determined to be significant predictors of autonomy. When the regression coefficients related to the prediction of autonomy were examined, a positive relationship between proactive coping dimension and secure attachment type and a negative relationship between avoidance coping dimension and preoccupied dimension were determined. Moreover, the prediction of autonomy by secure attachment and proactive coping dimensions and the positive relationship between these two variables were expected results.

\section{Discussion and Conclusion}

When the findings are examined, it is seen that attachment types and proactive personality structures are the predictors of the autonomy. Therefore, it is considered that the autonomy development in adoles- 
cence will be supported when the activities related to proactive personality and inter family relationality are included in the programs prepared by the schools' guidance services. Depending on the finding that the individuals who has secure attachment style use the proactive coping strategies, meeting the needs of the individual and providing it with a secure relationship environment in its babyhood will result in the development of a proactive personality in the adolescence. The schools' guidance services should inform the parents about this issue and draw attention to family-child relationship in order to support the development of proactive personality. Although the secure attachment style was a significant predictor of autonomy, it was determined that individuals with preoccupied personality also developed autonomous behaviors. It is suggested for future studies to examine this issue deeper.

\section{Giriş}

Ergenlik bireyin çocukluktan çıkıp yetişkinliğe geçişinin ilk ve sancılı evresidir. Gelişimsel bir süreci ifade eden firtına ve stres kaynağı olarak bilinen bu dönemde fiziksel ve bilişsel birtakım değişik ilişkiler yaşanmaktadır. Ergenlik döneminde bireyin yaşadığı kimlik arayışı ve kendi benliğini oluşturma çabaları özerklik gelişimi hızlanmaktadır. İçinde bulunulan koşullar ve sosyal psikolojik özellikler bireyin ergenlik döneminde daha çok kendine yetme ve özgür olma yaşantılarını desteklemektedir. Yani hem birey daha özerk olmak istemekte hem de sosyal alanda ortaya çıkan toplumsal ihtiyaçlar bireyin özerkliğinin temelini oluşturmaktadır. $\mathrm{Bu}$ dönemde bilişsel alanda 
bireyin kendi kararlarını alabilme potansiyeli artmakta, benlik ve kimlik gelişimi hızlanmakta, duygu ve davranışlar daha çok ergenin kendisi tarafından yönetilmeye başlanmaktadır (Grotevant ve Cooper, 1985; Zimmer, Gembeck ve Collins, 2003). Ergenlik döneminde yaşanan bu gelişmeler, yetişkinliğe geçişin temel görevi olarak kabul edilen özerklik gelişimini desteklemektedir.

Özerklik kelimesinin İngilizce karşılığı olan “aotonomy” kelimesi latince "autos", ve "nomos" sözcüklerinden oluşmaktadır. Noom’a (1999) göre, özerkliğin “öz” yani kişinin kendisi ile “erk” yani güç sözcüklerinin birleşiminden oluşmakta olup her bireyin kendi hayatına yön vermek için geliştirmeye ihtiyaç duyduğu kendi kendine yetebilme yetisidir. Türk Dil Kurumu'na (2005) göre, ise özerklik; bir topluluğun kendi uyacağı yasayı kendisinin koymasıdır. Özerklik, bireyin kendini yönetimi şeklinde ifade edilmekte olup zamanla farklı bakış açılarına göre tanımları yapılmıştır. Psikanalitik bakış açısına göre ergenlik döneminde özerkliğin özellikle aileden kopma ve ergenin ayrışma sürecindeki rolü üzerine vurgu yapılmıştır (Bowlby, 1982). Kendini Belirleme Kuramı'na göre özerklik, kişinin kararlarını dış baskılardan etkilenmeden kendisi alması olarak tanımlanmıştır. Bilişsel yaklaşımda ise özerklik gelişiminde karar vermenin önemi ve kontrol algısı üzerine yoğunlaşılmıştır (Deci ve Ryan, 2000). Kültürel psikolojide ise özerklik, daha çok benlik kurgusu üzerinden açıklanmaya çalışılmıştır. Sonuç olarak bakıldığında özerklik; duygusal, davranışsal ve bilişsel yapılardan meydana gelmektedir. Bilişsel boyutu bireyin kendine güveni, kendini kontrol edebileceği inancı ve bağımsız olarak 
karar vermeyi; duygusal boyutu, bireyin âileden ayrılıp bağımsızlaşması olarak ifade edilir. Davranışsal boyutu ise kendi davranışlarını düzenlemeyi ve kendi kararlarını almayı ve uygulamayı içeren aktif ve bağımsız bir işleyişi tanımlamaktadır (Sessa ve Steinberg, 1991). Bu işleyiş tarzı ise özerklikle ilgili zamanla değişen kuramsal bakış açı1larına bağlıdır. Özerklik gelişimi ile ilgili klasik yaklaşımların âileden kopma, ayrışma ve bireyselleşmeyi vurguladığı, daha güncel yaklaşımların ise bağlllık ve özerklik birlikteliğinin üzerinde durduğu görülmektedir (Steinberg, 2007). Özerklik gelişimine ilişkin bu kavramsal değişim oldukça önemlidir. İnsanın bağımsızlı̆̆ını anlamaya yönelik ilk çalışmalar özerkliğin daha çok âileden kopuş yönüne odaklanmışken daha sonra bağlanma ile bağımsızlığın, özerkliğin birlikte var olan ve gelişen özellikler olduğu anlaşılmaya başlanmıştır (Bowlby, 1982; Kağıtçıbaşı, 2007).

Klasik anlamda bağlanma bebek ve bakım veren kişi arasında kurulan bağdır. Özerklik gelişiminin temelleri bebeklik döneminde atılır; çünkü bebeğin temel ihtiyaçları karşılandığında ve bakım verenle arasında güvenli bir ilişki bulunduğunda bebek çevreyi keşfetme arayışına girer. Kısa dönemde bağlanma ve keşfetme birbirine karşıı gibi görünse de uzun dönemde birbirinin tamamlayıcısıdır; bağlanma çevreyi keşfetmek için gerekli olan güveni sağlamaktadır. Bağlanma kuramcıları keşfetme davranışını özerkliğin ilk göstergeleri olarak görmekte ve bağlanma ve özerklik arasındaki ilişkiye dikkat çekmektedirler (Bowlby, 1982). Bağlanma kuramına göre çocuk ve bakım veren arasında kurulan nitelikli ilişki çocuğun güvenlik gereksinimini karş1- 
ladığı gibi çocuğun bakım veren kişi tarafından algıladığı tutarlı, sıcak ve kabul edici davranışlar onun çevresine karşı özerklik gelişimini de desteklemektedir.

Deci ve Ryan'a göre (2000), öz yeterlik kuramında özerklik temel bir gereksinimdir ve kişi, kendi eylemlerinin kaynağı olarak kendini görmektedir, ergenlik döneminde bağımsızlık çabalarının yoğunlaştığını ve ergenlerin özerklik kazanmak, kimlik oluşturma yolunda risk alma olasılıklarının da arttığını söylemiştir; ayrıca günümüz gençlerinin kendileri ve çevreleri ile ilgili olarak önceki kuşaklardan daha fazla sorumlulukla karşı karşıya oldukları belirtmiştir (akt; Steinberg, 2002). Bireyselleşen toplumsal yapının gereği olarak kendini kanıtlamak, aktif olmak ve problem çözme becerilerini geliştirmek için bireyin sorumluluk almak, insiyatifi elinde bulundurmak gibi kişisel özelliklerini geliştirmesi gerekmektedir.

Proaktif kişiler; gerçekçi olan ve bu şekilde davranan, risk alabilen, riskin sorumluluklarını üstlenen ve olumsuzlukları fırsata çeviren, çevresine yönelik bir etki alanı oluşturan kişilerdir (Bateman ve Crant, 1993; Bridge, Neil ve Cromine, 1998; Bowers, 1973). Bu çalışmada özerklik ve proaktif kişilik kavramlarının birlikte ele alınması bu sebeptendir. Birey kendini ne kadar bağımsız, yani özgür ve bir şeyleri yapabilir yeterlilikte görürse o derece olayları değiştirme sorumluluğunu alabilir. İlgili alanyazın incelemesi yapıldığında ergenlikte bağlanma stilleri, özerklik ve proaktif kişilik yapılarını birlikte inceleyen bir araştırmaya rastlanmamıştır. Bu nedenle bu araştırma ile ergenlikte bağlanma stilleri, özerklik ve proaktif kişilik yapıları çeşitli 
değişkenler açısından incelenerek elde edilen bulguların alana katkı sağlaması umulmaktadır. Ayrıca konu ile ilgili ülkemizde yapılan çalışmaların çok sınırlı sayıda olmasından dolayı araştırma bulguları ortaöğretim programlarında ara disiplin olarak sağlıklı kişilik gelişimine daha çok yer verilmesi ve bu sayede öğrencilerin gelişimine katkı sağlanması düşünülmektedir. Özerkliğin yordayıcısı olarak bağlanma stilleri ve proaktif kişilik yapılarının incelenmesi sonucunda ortaya çıkan bulguların; özellikle ergenlikte karşımıza çıkan ebeveyn çatışmaları, madde bağımlılı̆̆ı, intihar, cinsel istismar, disiplin bozucu davranışlar, okul ortamlarında disiplin problemlerinin yaşanması gibi durumlar karşısında âilelerin ve okul yönetimlerinin önleyici çözümler üretmesinde yardımcı olacağı düşünülmektedir. Bu çalışmanın âile ve okul ortamlarında konu ile ilgili bilinç düzeyini arttıracağı düşünülmekte olup çalışmanın çıktıları ile ergenlikte kişilik gelişiminin önemli bileşenleri olan özerklik gelişimin desteklenmesi bağlanma davranışının öneminin âileler tarafından anlaşılması ve özerk birey olma, sorumluluk üstlenebilme problem çözme gibi gerekli davranışların kazandırılması konusunda öğrencilerin desteklenmesi gerektiği düşünülmektedir. Türk Eğitim Sistemi içinde rehberlik ve psikolojik danışma servislerinin işleyişi düşünüldüğünde; önleyici rehberlik kapsamında ergenlik çağındaki bireylerin âile ve toplum tarafından ayrışma-bireyselleşme sürecinde desteklenmesi gerekmektedir. Kendi yeterlilik alanlarının farkına varabilmeleri için çalışma bulgularının bu doğrultuda alana katkı sağlayacağı düşünülmektedir. Bu gerekçeler ile ergenler üzerine özerklik, bağlanma sitilleri ve proaktif kişilik yapılarına ele alan bir çalışmaya ihtiyaç olduğu anlaşılmaktadır. 
$\mathrm{Bu}$ nedenle ergenlerde bağlanma stilleri ile proaktif kişilik yapılarının özerklik üzerindeki yordayıcı rolünün incelenmesi bu araştırmanın temel amacını oluşturmaktadır. Ayrıca cinsiyet, kardeş sayıları, doğum sırası, algılanan sosyo-ekonomik durum ve en uzun süre yaşanılan yerleşim yeri gibi bağımsız değişkenlere göre ergenlerin özerklik gelişiminde, bağlanma stillerinde ve proaktif kişilik yapılarında anlamlı bir farklılığın olup olmadığının incelenmesi bu araştırmanın amaçları arasındadır. Çalışmada belirtilen amaçlar doğrultusunda aşağıdaki alt problemlere cevap aranacaktır:

1. Ergenlerin bağlanma stilleri ve proaktif kişilik yapıları özerkliğin anlamlı bir yordayıcısı mıdır?

2. Ergenlerin özerklik düzeyleri cinsiyet ve algılanan sosyo-ekonomik durum ve en uzun süre yaşanılan yerleşim yerine göre anlamlı bir farklılık göstermekte midir?

2. Ergenlerin bağlanma stilleri cinsiyet ve algılanan sosyo-ekonomik durum ve en uzun süre yaşanılan yerleşim yerine göre anlamlı bir farklılık göstermekte midir?

3. Ergenlerin proaktif kişilik yapıları cinsiyet ve algılanan sosyo-ekonomik durum ve en uzun süre yaşanılan yerleşim yerine göre anlamlı bir farklılık göstermekte midir? 


\section{Yöntem}

\section{Araştırma Modeli}

$\mathrm{Bu}$ araştırma ergenlerde; özerklik, bağlanma stilleri ve proaktif kişilik yapıları arasında anlamlı bir ilişkinin olup olmadığının araştırıldığı ve demografik özelliklere bağlı olarak değişimlerin incelendiği ilişkisel tarama modelinde bir çalışmadır.

\section{Çalışma Grubu}

Araştırma, 2011-2012 eğitim öğretim yılında Ankara Mamak ilçe merkezinde 2 anadolu lisesi, 3 meslek lisesi ve 2 genel lisede öğrenim gören öğrencilerle yürütülmüştür. Araştırma, 249 kız ve 174 erkek olmak üzere toplam 423 öğrenciden oluşan çalışma grubu ile yapılmış, ölçme araçları araştırmacı tarafından uygulanarak veriler toplanmıştır.

\section{Veri Toplama Araçları}

Araştırmada verileri toplamak için dört ölçme aracından oluşan bir batarya kullanılmıştır. İlki araştırmacı tarafından örneklem grubu ile ilgili sosyo-demografik verileri toplamak amacıyla geliştirilen "Kişisel Bilgi Formu"dur. İkincisi öğrencilerin özerklik gelişimlerini ölçmek için kullanılan "Ergen Özerklik Ölçeği”'dir. Ölçek; Noom, Dekovic ve Meeus (2001) tarafından 12-18 yaşları arasındaki ergenlerin özerkliğe ilişkin algılarını ölçmek amacı ile geliştirilmiştir. Türkçeye uyarlaması ise Musaağaoğlu ve Güre (2004) tarafindan yapılmıştır. Üçüncüsü Ergenlerin bağlanma stillerini ölçmek amacı ile (Bartholomew ve Horowitz, 1991) geliştirilen “İlişki Ölçekleri Anketi”dir. Ölçeğin Türkçeye uyarlanması ise Sümer ve Güngör (1999) tarafından yapılmıştır. Dördüncüsü ise orijinali Greenglass, Schwarzer, Jakubiec, 
Fiksenbaum ve Taubert (1999) tarafından geliştirilmiş olan Şahin (2006) tarafından Türkçe uyarlaması yapılan "Proaktif Başa Çıkma Envanteri"dir.

\section{Verilerin Analizi}

Araştırma verilerinin toplanmasından sonra; Ergen Özerklik Ölçeği, Proaktif Başa Çıkma Envanteri, İlişki Ölçekleri Anketi ve Kişisel Bilgi Formu'ndan toplanan verilerin işlenmesi ve yorumlanması için SPSS (Statistical Package for Social Sciences) kullanılmıştır. Ham veriler öncelikle bu programa aktarılmış ve analize hazır hâle getirilmiştir. Daha sonra ise SPSS programı kullanılarak analizler yapılmıştır. Verilerin analizi için "İlişkisiz Örneklemler İçin t Testi” ve "İlişkisiz Örneklemler İçin Tek Faktörlü ANOVA" analizleri ve “Çoklu Regresyon” analizlerinden yararlanılmıştır.

\section{Bulgular}

Bu bölümde; araştırmanın temel amacı, bu amaç doğrultusunda belirlenen alt problemler ve uygulanan analizler, bunlara âit bulgular tablolar yardımıyla açıklanmıştır.

\section{Alt Problem 1: Ergenlerin Bağlanma Stilleri ve Proaktif Kişilik Yapıları Özerklik Gelişimlerinin Anlamlı Bir Yordayıcısı mıdır?}

Araştırmanın yukarıda verilen alt problemine yönelik gerekli varsayımların karşılandığı anlaşıldıktan sonra korelasyon ve regresyon analizleri yapılmış ve bulgular aşağıda tablolar şeklinde verilerek açıklanmıştır. 


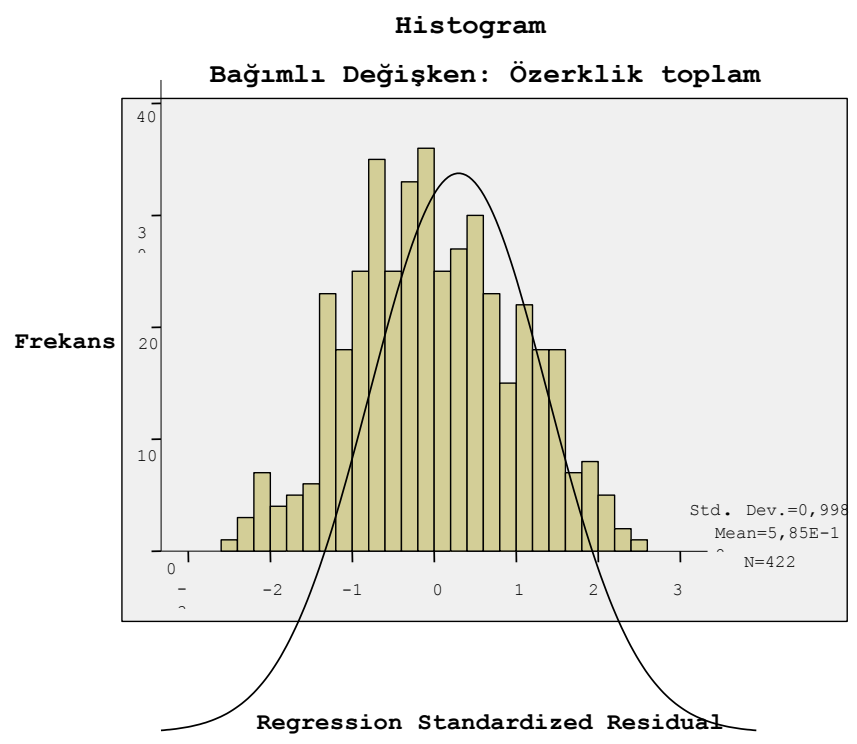

Grafik 1. Normallik dağılımı.

Grafik 1'den anlaşıldığı gibi araştırma konusu olan bağımlı değişkenin yani özerkliğe ait puan dağılımının normal dağılım özelliklerine uygun olduğu görülmektedir.

Grafik 2 incelendiğinde bağımlı değişken olan özerklik açısından noktaların bir eksen etrafında toplandığı ve doğrusal bir ilişki gösterdiği anlaşılmaktadır. Bu sonuçlara dayanarak regresyon analizinin ön koşulu olan normallik ve doğrusallık varsayımlarının karşılandığg sonucuna varılmıştır. 
Normal P-P Plot of Regression Standardized Residual

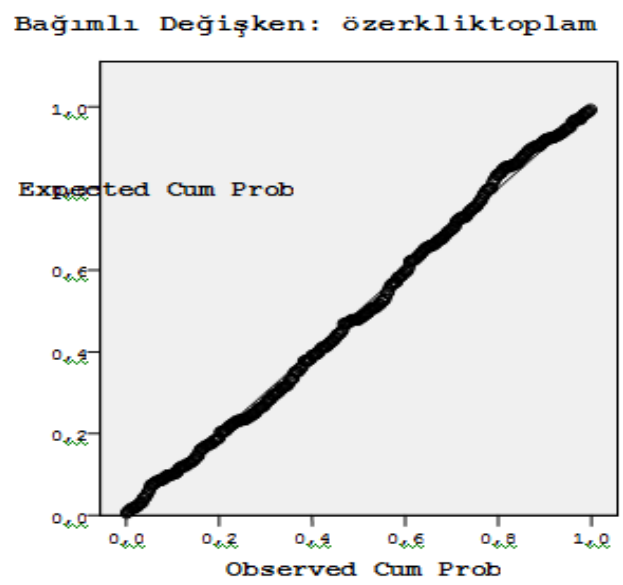

Grafik 2. Doğrusallık dağglımı.

Bu çalışma, ele alınan bağımsız değişkenlerin özerkliği yordayıp yordamadığını belirlemeden önce, analizde kullanılacak bağlanma stilleri ve proaktif kişilik yapısı değişkenlerinin çoklu bağlantı sorunu oluşturup oluşturmadığına bakmak için değişkenler arasındaki ilişkiler korelasyon testi ile tespit edilmiş olup Tablo 1'de verilmiştir.

Tablo 1'de görüldüğü üzere değişkenler arasındaki istatistiksel olarak anlamlı ilişkiler \pm 0.01 ile \pm 0.59 arasında değişmektedir. Bağımsız değişkenler arasındaki ilişkinin .80 üzerinde olması çoklu bağlantı sorununun olabileceği şeklinde yorumlanmaktadır (Büyüköztürk, 2011). Bu çalışmada regresyon analizinde kullanılan bağlanma stilleri ve proaktif kişilik yapısı olan bağımsız değişkenler arasındaki ilişkinin .80 ve üzeri olmadığından dolayı, değişkenler arasında çoklu bağlantı sorunu olmadığını söylemek mümkündür. Analize dâhil edilen değişs- 
kenlere âit dağılımların normal dağılım gösterdiği, artık değerlerin olmadığı ve ayrıca çoklu bağlantı olmadığı tespit edilmiştir.

Tablo 1. Bağlanma Stilleri İle Proaktif Kişilik Yapısı Alt Boyutlarına Ait Korelasyon

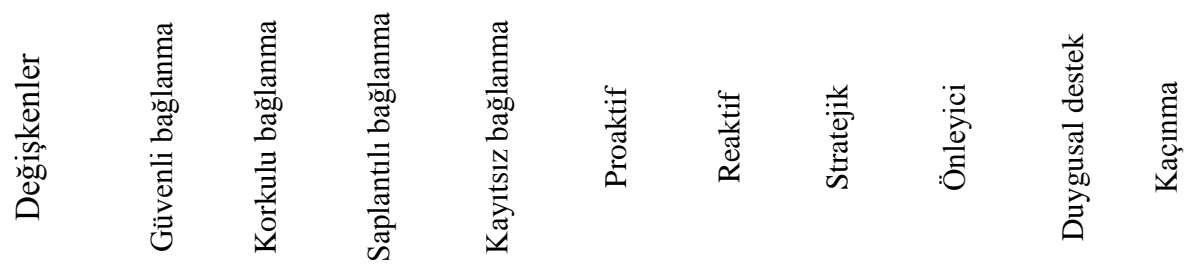

\begin{tabular}{|c|c|c|c|c|c|c|c|c|c|c|}
\hline $\begin{array}{l}\text { Güvenli } \\
\text { bağlanma }\end{array}$ & 1 & & & & & & & & & \\
\hline $\begin{array}{l}\text { Korkulu } \\
\text { bağlanma }\end{array}$ & -.052 & 1 & & & & & & & & \\
\hline $\begin{array}{l}\text { Saplantılı } \\
\text { bağlanma }\end{array}$ & .037 & .048 & 1 & & & & & & & \\
\hline $\begin{array}{l}\text { Kayıtsız } \\
\text { bağlanma }\end{array}$ & -.015 & $.446^{* *}$ & .029 & 1 & & & & & & \\
\hline Proaktif & .078 & .068 & -.044 & $.130^{* *}$ & 1 & & & & & \\
\hline Reaktif & .055 & .029 & -.015 & $.108^{*}$ & $.426^{* *}$ & 1 & & & & \\
\hline Stratejik & .034 & $.154^{* *}$ & -.008 & $.163^{* *}$ & $.518^{* *}$ & $.460^{* * *}$ & 1 & & & \\
\hline Önleyici & .090 & $.106^{*}$ & $-.129^{* *}$ & $.126^{*}$ & $.507^{* *}$ & $.375^{* *}$ & $.586^{* *}$ & 1 & & \\
\hline $\begin{array}{l}\text { Duygusal } \\
\text { destek }\end{array}$ & .058 & $.107^{*}$ & .057 & $.207^{* *}$ & $.252^{* *}$ & $.309^{* *}$ & $.253^{* *}$ & $.201^{* *}$ & 1 & \\
\hline Kaçınma & .054 & .096 & $.134^{* *}$ & $.196^{* *}$ & -.088 & -.058 & .001 & -.006 & $.209^{* *}$ & 1 \\
\hline
\end{tabular}

Analizin varsayımları karşılandıktan sonra aşamalı çoklu regresyon analizi yapılmış, analiz sonuçları Tablo 2'de verilmiştir. 
Tablo 2. Öğrencilerin Özerklik Düzeylerinin Yordanmasına İlişkin Aşamalı Regresyon Analizi

\begin{tabular}{|c|c|c|c|c|c|c|c|c|c|}
\hline \multirow{2}{*}{ Değişkenler } & \multirow[b]{2}{*}{$\mathbf{B}$} & \multirow[b]{2}{*}{$\boldsymbol{\beta}$} & \multirow[b]{2}{*}{$\mathbf{R}$} & \multirow{2}{*}{$\mathbf{R 2}$} & \multirow{2}{*}{$\begin{array}{c}\text { Tahminin } \\
\text { Standart } \\
\text { Hatası }\end{array}$} & \multicolumn{4}{|c|}{ Değişim İstatistikleri } \\
\hline & & & & & & $\begin{array}{c}\text { R2 } \\
\text { Değişim }\end{array}$ & $\underset{\text { Değişim }}{\text { F }}$ & SD & $p$ \\
\hline Sabit & 28.66 & & & & & & & & \\
\hline $\begin{array}{l}\text { Proaktif başa } \\
\text { çıkma (1) }\end{array}$ & .850 & .409 & $.432 \mathrm{a}$ & .187 & .185 & .187 & 96.706 & 1.421 & .000 \\
\hline $\begin{array}{l}\text { Güvenli } \\
\text { Bağlanma(2) }\end{array}$ & .191 & .125 & $.448 b$ & .200 & .196 & .013 & 7.090 & 1.420 & .008 \\
\hline $\begin{array}{l}\text { Saplantılı } \\
\text { bağlanma (3) }\end{array}$ & -.164 & -.094 & $.460 \mathrm{c}$ & .211 & .205 & .011 & 5.762 & 1.419 & .017 \\
\hline $\begin{array}{l}\text { Kaçınma başa } \\
\text { ç1kma(4) }\end{array}$ & -.345 & -.091 & $.468 \mathrm{~d}$ & .219 & .212 & .008 & 4.370 & 1.418 & .037 \\
\hline
\end{tabular}

Özerklik $=28.667+0.850$ proaktif başa çıkma(1) +0.191 güvenli bağlanma $(2)-0.164$ saplantılı bağlanma(3) - 0.345 kaçınma başa çıkma(4)
a. (Sabit), proaktif başa çıkma
b. (Sabit), proaktif başa çıkma, güvenli bağlanma
c. (Sabit), proaktif başa çıkma, güvenli bağlanma, saplantılı bağlanma
d. (Sabit), proaktif başa çıkma, güvenli bağlanma, saplantılı bağlanma, ka- çınma başa çıkma

Öğrencilerin özerklik düzeylerinin yordanmasına ilişkin yapılan aşamalı regresyon analizinin dört aşamada tamamlandığı ve özerkliğe âit toplam varyansın dört değişken tarafından sadece \%22'sinin açıklanabildiği diğer \%78'in ise başka değişkenlerce açıklanabildiği söylenebilir. Öğrencilerin özerliklerinin \%18.7'si analize ilk merhalede giren proaktif başa çıkma boyutu tarafından açıklamaktadır. Bunu, \%1.3’ü güvenli bağlanma takip etmektedir. Analize üçüncü merhalede giren saplantılı bağlanma ise özerkliğe ilişkin varyansın \%1.1'ini açıklamakta ve son olarak da özerkliğe ilişkin varyansın \%0.8'ini 
açıklayan kaçınma başa çıkma becerisi olmaktadır. Regresyon katsayılarının işaretlerine bakıldığında ise proaktif başa çıkma ile güvenli bağlanma stiline âit puanlar arasında pozitif yönde korelasyon varken saplantılı bağlanma ile kaçınma başa çıkma arasında ise negatif yönde korelasyon bulunmaktadır. Özerkliğin proaktif başa çıkma ve güvenli bağlanma boyutlarıyla büyük oranda açıklanıyor olması ve iki boyut arasında pozitif yönlü bir korelasyonun olması, araştırmada beklenen bir sonuçtur.

\section{Alt Problem 2: Araştırmaya Katılan Ergenlerin Özerklik Düzey- leri Cinsiyet, Algılanan Sosyo-ekonomik Durumuna Göre Anlamlı Bir Farklıık Göstermekte midir?}

Araştırmanın yukarıda verilen alt problemine yönelik t-testi ve varyans analizleri yapılmış ve bulgular sırasıyla tablolar şeklinde verilerek açıklanmıştır.

Öğrencilerin özerklik düzeyleri cinsiyet değişkenine göre incelenmesi

Öğrencilerin özerkliklerinin cinsiyetlerine göre anlamlı bir farkl1lık gösterip göstermediğini belirlemek amacıyla, kız ve erkeklere âit dağılımların normal dağılım göstermesi ve gruplardaki örneklem sayıları dikkate alınarak t testi kullanılmış ve analiz sonuçları Tablo 3 'te verilmiştir. 
Tablo 3. Öğrencilerin Özerklik Düzeylerinin Cinsiyete Göre t-testi Sonuçları

\begin{tabular}{lcccccc}
\hline Cinsiyet & $\mathbf{N}$ & $\bar{X}$ & ss & Sd & t & $\boldsymbol{p}$ \\
\hline Erkek & 174 & 51.82 & 8.42 & 421 & -.127 & .899 \\
Kız & 249 & 51.92 & 7.60 & & & \\
\hline
\end{tabular}

Analiz sonuçlarına göre, öğrencilerin özerklik düzeylerinde istatistiksel olarak anlamlı bir farklılık bulunmamaktadır [ $[\mathrm{t}(421)=-127$, $p>.05]$. Bir başka ifadeyle erkek ve kız öğrencilerin benzer düzeyde özerkliğe sâhip oldukları söylenebilir.

\section{Öğrencilerin özerklik düzeylerinin algılanan sosyo-ekonomik duruma göre incelenmesi}

Gruplara âit puanların normal dağılması, gruplara âit varyansların homojen olması gibi varsayımların karşılandığı anlaşıldıktan sonra öğrencilerin özerklik düzeylerine âit puan ortalamalarının sosyo-ekonomik durumlarına göre istatistiksel olarak anlamlı bir farkl111ğın olup olmadığını test etmek amacıyla tek yönlü varyans analizi (ANOVA) kullanılmış ve analiz sonuçları ise Tablo 4 'te verilmiştir.

Tablo 4 incelendiğinde öğrencilerin özerklik seviyelerine âit puan ortalamaları sosyo-ekonomik durumlarına göre tek yönlü varyans analizi ile karşılaştırıldığında, özerklik düzeyleri sosyo-ekonomik durumlarına göre anlamlı bir farklılık göstermemektedir $[F(4-418)=0.728, p>.05]$. Sosyo-ekonomik durumlarına göre puan ortalamalarına bakıldığında, ekonomik düzey arttıkça gruplara âit puan 
ortalamalarının görece arttığı; ancak bu artışın istatistiksel olarak anlamlı olmadığı test edilmiştir.

Tablo 4. Öğrencilerin Özerklik Düzeylerinin Sosyo-ekonomik Durumlarına Göre Anova Testi Sonuçları

\begin{tabular}{ccccccccc}
\hline & Değişkenler & $\mathbf{N}$ & $\bar{X}$ & ss & Sd & $\mathbf{F}$ & $\boldsymbol{p}$ & $\begin{array}{c}\text { Anlamlı } \\
\text { Fark }\end{array}$ \\
\hline \multirow{4}{*}{ Özerklik } & 1501-2250TL ve altı & 90 & 50.00 & 4.78 & & & & \\
& $751-1500 \mathrm{TL}$ & 198 & 51.34 & 5.49 & & & & \\
& 2251-3000TL & 30 & 53.41 & 4.46 & & & & \\
& 3000TL ve üstü & 30 & 49.17 & 2.60 & & & & \\
\hline
\end{tabular}

Alt Problem 3: Araştırmaya Katılan Ergenlerin Bağlanma Stilleri Cinsiyet, Algılanan Sosyo-ekonomik Durumuna Göre Anlamlı Bir Farklılık Gözlenmekte midir?

Araştırmanın yukarıda verilen alt problemine yönelik $\mathrm{t}$ testi ve varyans analizleri yapılmış ve bulgular sırasıyla tablolar şeklinde verilerek açıklanmıştır.

Öğrencilerin bağlanma stillerinin cinsiyetlerine göre incelenmesi

Öğrencilerin cinsiyetlerine göre bağlanma stillerinin karşılaşt1rılması için, her bir bağlanma stili ayrı ayrı bağımlı değişken olarak ele alınmıştır. Öğrencilerin her bir değişkene âit puanları cinsiyetlerine göre normal dağılım gösterdiğinden ve gruplardaki örneklem sayılarından dolayı ilişkisiz t testi kullanılmıștır. Her bir bağlanma stiline göre analiz sonuçları aşağıda Tablo 5 'te verilmiştir. 
Tablo 5. Öğrencilerin Bağlanma Stillerinin Cinsiyete Göre t testi Sonuçları

\begin{tabular}{llcccccc}
\hline $\begin{array}{l}\text { Bağlanma } \\
\text { Stili }\end{array}$ & Cinsiyet & $\mathbf{N}$ & $\bar{X}$ & ss & Sd & t & $\boldsymbol{p}$ \\
\hline $\begin{array}{l}\text { Güvenli } \\
\text { Bağlanma }\end{array}$ & Erkek & 174 & 22.14 & 4.79 & 421 & 2.57 & $0.01^{*}$ \\
& K1z & 249 & 20.83 & 5.39 & & & \\
$\begin{array}{l}\text { Korkulu } \\
\text { bağlanma }\end{array}$ & Erkek & 174 & 19.98 & 5.03 & 421 & -2.34 & $0.01^{*}$ \\
& Kiz & 249 & 18.15 & 5.08 & & & \\
$\begin{array}{l}\text { Saplantılı } \\
\text { bağlanma }\end{array}$ & Erkek & 174 & 19.88 & 4.37 & 421 & 2.93 & $0.04^{*}$ \\
$\begin{array}{l}\text { Kayıts1z } \\
\text { Kağlanma }\end{array}$ & Erkek & 174 & 24.12 & 5.73 & 421 & -0.68 & 0.49 \\
\hline
\end{tabular}

Yukarıdaki tabloda görüldüğü üzere, öğrencilerin güvenli bağlanma $[\mathrm{t}(421)=2.574, \quad p<.05]$, korkulu bağlanma $[\mathrm{t}(421)=-2.345$, $p<.05]$ ve saplantılı bağlanma $[\mathrm{t}(421)=2.933, p<.05]$ stillerinde cinsiyete göre anlamlı bir farklılık olduğu anlaşılmaktadır. Bir diğer ifadeyle öğrencilerin cinsiyete göre farklı düzeylerde bağlanma gösterdikleri söylenebilir. Güvenli bağlanma ile saplantılı bağlanma stilinde, erkekler kızlara oranla daha fazla puan ortalamasına sâhiptirler. Korkulu bağlanma stilinde ise kız öğrencilerin puan ortalamaları erkeklere oranla daha fazladır. Elde edilen bulgulara göre erkekler kızlara göre daha fazla güvenli ve saplantılı bağlanma gösterirken kızlar daha fazla korkulu bağlanma göstermektedirler. Kayıtsız bağlanma stilinde ise erkek ve kız öğrenciler arasında anlamlı farklılık olmadığı test edilmiştir. 


\section{Öğrencilerin bağlanma stillerinin algılanan sosyo-ekonomik}

\section{durumlarına göre incelenmesi}

Öğrencilerin güvenli bağlanma, korkulu bağlanma, saplantılı bağlanma, kayıtsız bağlanma stillerinin algılanan sosyo-ekonomik durumlarına göre anlamlı bir farklılık gösterip göstermediği belirlemek amacıyla, tek yönlü varyans analizinin varsayımlarına bakılmıştır. Öğrencilerin korkulu bağlanma stilinde, sosyo-ekonomik durumlarına göre varyansların homojenliğe ilişkin varsayım karşılanmadığı için Kruskal Wallis H testi, diğer üç stilde ise varyansların homojenliği ile ANOVA'nın diğer varsayımları karşılandığı için tek yönlü varyans analizi kullanılmıştır. Analiz sonuçları aşağıda Tablo 6' da verilmiştir.

Tablo 6. Öğrencilerin Bağlanma Stillerinin Algılanan Sosyo-ekonomik Durumlarına Göre Anova Testi Sonuçları

\begin{tabular}{|c|c|c|c|c|c|c|c|c|}
\hline $\begin{array}{l}\text { Bağlanma } \\
\text { Stilleri }\end{array}$ & $\begin{array}{l}\text { Algilanan Sos- } \\
\text { yo-Ekonomik } \\
\text { Durum }\end{array}$ & $\mathbf{N}$ & $\bar{X}$ & SS & Sd & $\mathbf{F}$ & $p$ & $\begin{array}{c}\text { Anlamlı } \\
\text { Fark }\end{array}$ \\
\hline \multirow{5}{*}{$\begin{array}{c}\text { Güvenli } \\
\text { Bağlanma }\end{array}$} & 750 TL ve altı & 90 & 20.00 & 4.78 & \multirow{5}{*}{$\begin{array}{c}4 \\
418\end{array}$} & \multirow{5}{*}{4.22} & \multirow{5}{*}{.002} & \multirow{5}{*}{$\begin{array}{l}1-2,1-3 \\
1-4,1-5 \\
2-4,2-5\end{array}$} \\
\hline & 751-1500TL & 198 & 21.34 & 5.49 & & & & \\
\hline & $1501-2250 \mathrm{TL}$ & 75 & 21.66 & 5.07 & & & & \\
\hline & 2251-3000TL & 30 & 23.41 & 4.46 & & & & \\
\hline & 3000TL ve üstü & 30 & 24.17 & 2.60 & & & & \\
\hline \multirow{5}{*}{$\begin{array}{l}\text { Saplantılı } \\
\text { Bağlanma }\end{array}$} & 750 TL ve altı & 90 & 16.72 & 4.75 & \multirow{5}{*}{$\begin{array}{c}4 \\
418\end{array}$} & \multirow{5}{*}{.703} & \multirow{5}{*}{.590} & \multirow{5}{*}{----} \\
\hline & 751-1500TL & 198 & 15.83 & 4.57 & & & & \\
\hline & $1501-2250 \mathrm{TL}$ & 75 & 16.33 & 4.54 & & & & \\
\hline & 2251-3000TL & 30 & 15.86 & 3.84 & & & & \\
\hline & 3000TL ve üstü & 30 & 15.72 & 4.36 & & & & \\
\hline \multirow{5}{*}{$\begin{array}{l}\text { Kayıtsız } \\
\text { Bağlanma }\end{array}$} & 750 TL ve altı & 90 & 24.86 & 5.62 & \multirow{5}{*}{$\begin{array}{c}4 \\
418\end{array}$} & \multirow{5}{*}{$\begin{array}{c}1.62 \\
6\end{array}$} & \multirow{5}{*}{.166} & \multirow{5}{*}{----} \\
\hline & 751-1500TL & 198 & 24.44 & 5.58 & & & & \\
\hline & $1501-2250 \mathrm{TL}$ & 76 & 24.36 & 5.71 & & & & \\
\hline & 2251-3000TL & 30 & 21.83 & 5.55 & & & & \\
\hline & 3000TL ve üstü & 30 & 24.61 & 7.37 & & & & \\
\hline
\end{tabular}


Tablo 6'da görüldüğü üzere; öğrencilerin saplantılı bağlanma $[F(4-418)=0.703, p>.05]$ ile kayıtsız bağlanma $[F(4-418)=1.626$, $p>.05]$ stillerinde sosyo-ekonomik durumlarına göre anlamlı bir farklılık görülmezken güvenli bağlanma stilinde ise sosyo-ekonomik duruma göre anlamlı bir farklılık olduğu test edilmiştir $[\mathrm{F}(4-418)=4.22$, $p$ <.05]. Bir diğer ifadeyle öğrencilerin güvenli bağlanma stilleri üzerinde algılanan sosyo-ekonomik durumlarının etkili olduğudur. Gruplar arasındaki farklılığı belirlemek amacıyla yapılan LSD analizi sonucunda, sosyo-ekonomik durumu 750 TL ve altı olan yani alt sosyo-ekonomik düzeydeki öğrencilerin, güvenli bağlanma puanlarının diğer yüksek gelirli öğrencilerden daha düşük olduğu anlaşılmaktadır. Ayrıca sosyo-ekonomik durumu 751-1500 TL olan öğrenciler ise geliri 2250 TL üstünde olan öğrencilerden güvenli bağlanma puanlarının anlamlı düzeyde düşük olduğu anlaşılmaktadır. Öğrencilerin korkulu bağlanma stillerine âit puan ortalamalarının sosyo-ekonomik düzeye göre karşılaştırılmasında Kruskal Wallis H testi kullanılmış ve analiz sonuçları Tablo 7'de verilmiştir.

Tablo 7. Öğrencilerin Korkulu Bağlanma Stillerinin Sosyo-ekonomik Durumlarına göre Kruskal Wallis H Testi Sonuçları

\begin{tabular}{lccccc}
\hline $\begin{array}{l}\text { Alglanan } \\
\text { Gelir Durumu }\end{array}$ & N & Sira Ort. & Sd & $\mathbf{X}^{\mathbf{2}}$ & $\boldsymbol{p}$ \\
\hline 750TL ve altı & 90 & 225.60 & 4 & 5.029 & .284 \\
751-1500TL & 197 & 215.44 & & & \\
1501-2250TL & 76 & 204.71 & & & \\
2251-3000TL & 30 & 192.74 & & & \\
3000TL ve üstü & 30 & 164.50 & & & \\
Toplam & 423 & & & & \\
\hline
\end{tabular}


Öğrencilerin korkulu bağlanma stilleri algılanan sosyo-ekonomik durumlarına göre anlamlı bir farklılık göstermemektedir $\left[X^{2}(4)=5.029\right.$, $p>.05]$. Gruplara âit sıra ortalamalarına bakıldığında ise ekonomik düzey arttıkça bireylerdeki korkulu bağlanma düzeylerinin düştüğü görülmektedir. Bu düşüş görece olup istatistiksel olarak anlamlı değildir.

\section{Alt Problem 4: Araştırmaya Katılan Ergenlerin Proaktif Kişilik Yapıları Cinsiyet, Algılanan Sosyo-ekonomik Duruma Göre An- lamlı Bir Farklılık Göstermekte midir?}

Araştırmanın yukarıda verilen alt problemine yönelik t-testi ve varyans analizleri yapılmış ve bulgular sırası tablolar şeklinde verilerek açıklanmıştır.

\section{Öğrencilerin proaktif başa çıkma becerilerinin cinsiyetlerine} göre incelenmesi

Öğrencilerin proaktif kişilik yapıları başa çıkma becerilerinin (Proaktif Başa Çıkma, Reaktif Başa Çıkma, Stratejik Plânlama, Önleyici Başa Çıkma, Aracı Destek Arayışı, Duygusal Destek Arayışı, Kaçınma Başa Çıkma) cinsiyetlerine göre anlamlı bir farklılık gösterip göstermediğini belirlemek amacıyla her bir alt boyut için dağılımların normalliğine bakılmıştır. Kız ve erkek öğrencilerin altı kişilik özelliğine âit dağılımlarının normal dağılım özelliği gösterdiği, gruplara âit örneklem sayıları ve kişilik özelliklerine âit puanların eşit aralıklı düzeyde olmalarından dolayı gruplararası karşılaştırmalar için ilişkisiz t testi kullanılmıştır. Analiz sonucunda elde edilen bulgular Tablo 8'de verilmiştir. 
Tablo 8. Öğrencilerin Proaktif Başa Çıkma Beceri Puanların Cinsiyete Göre t-testi Sonuçları

\begin{tabular}{|c|c|c|c|c|c|c|c|}
\hline $\begin{array}{l}\text { Proaktif Başa } \\
\text { Çıkma Becerileri }\end{array}$ & Cinsiyet & $\mathbf{N}$ & $X$ & SS & Sd & $\mathbf{t}$ & $p$ \\
\hline \multirow{2}{*}{$\begin{array}{l}\text { Proaktif Başa } \\
\text { Çıkma }\end{array}$} & $\mathrm{K}_{1 \mathrm{Z}}$ & 249 & 29.06 & 3.47 & \multirow{2}{*}{423} & \multirow{2}{*}{-2.61} & \multirow{2}{*}{$.0009 * *$} \\
\hline & Erkek & 174 & 28.18 & 3.82 & & & \\
\hline \multirow{2}{*}{$\begin{array}{l}\text { Reaktif Başa } \\
\text { Ç1kma }\end{array}$} & $\mathrm{K}_{1 \mathrm{Z}}$ & 249 & 22.16 & 3.14 & \multirow{2}{*}{423} & \multirow{2}{*}{-2.92} & \multirow{2}{*}{$0.004 * *$} \\
\hline & Erkek & 174 & 21.22 & 3.23 & & & \\
\hline \multirow{2}{*}{$\begin{array}{l}\text { Stratejik } \\
\text { Planlama }\end{array}$} & $\mathrm{K}_{1 \mathrm{Z}}$ & 249 & 26.92 & 3.91 & \multirow{2}{*}{423} & \multirow{2}{*}{-2.02} & \multirow{2}{*}{$0.044^{*}$} \\
\hline & Erkek & 174 & 26.12 & 4.01 & & & \\
\hline \multirow{2}{*}{$\begin{array}{l}\text { Önleyici Başa } \\
\text { Çıkma }\end{array}$} & $\mathrm{K}_{1 \mathrm{Z}}$ & 249 & 15.74 & 2.30 & \multirow{2}{*}{423} & \multirow{2}{*}{2.42} & \multirow{2}{*}{0.809} \\
\hline & Erkek & 174 & 15.80 & 2.50 & & & \\
\hline \multirow{2}{*}{$\begin{array}{l}\text { Araci Duygusal } \\
\text { Destek }\end{array}$} & $\mathrm{K} 1 \mathrm{Z}$ & 249 & 39.49 & 5.35 & \multirow[b]{2}{*}{423} & \multirow[t]{2}{*}{-2.35} & \multirow{2}{*}{$0.019 *$} \\
\hline & Erkek & 174 & 38.14 & 6.24 & & & \\
\hline Kaçınmacı Başa & $\mathrm{K}_{1 \mathrm{z}}$ & 249 & 29.06 & 3.47 & & \multirow[t]{2}{*}{1.67} & \multirow{2}{*}{0.095} \\
\hline Çıkma & Erkek & 174 & 28.11 & 3.82 & 423 & & \\
\hline
\end{tabular}

Yukarıdaki tablodaki veriler incelendiğinde öğrencilerin proaktif başa çıkma becerilerinin cinsiyete göre karşılaştırmaları sonucunda; proaktif başa çıkma alt boyutunda $[\mathrm{t}(423)=-2.614, p<.001]$, reaktif başa çıkma alt boyutunda $[\mathrm{t}(423)=-2.922, p<.01]$, stratejik plânlama alt boyutunda $[\mathrm{t}(406)=-2.024, p<.05]$, ve arac1 duygusal destek boyutunda [t(423)=-2.350, $p<.05]$ cinsiyete göre k1z öğrenciler lehine anlamlı bir farkl11ık oluştuğu tespit edilmiştir. Bu dört başa çıkma becerilerinde, kız ve erkek öğrencilerin puan ortalamalarına bakıldığında kız öğrencilerin daha yüksek puan ortalamasına sâhip oldukları görülmektedir. Buna göre kız öğrencilerin erkek öğrencilere oranla daha fazla proaktif 
başa çıkma, reaktif başa çıkma, stratejik plânlama başa çıkma ve aracı duygusal desteğe başvurma becerilerini kullandığı söylenebilir. Ancak katılımcıların önleyici başa çıkma [t(423)=2.42, $p$ >.05] ve kaçınmacı başa çıkma [t(423)=1.67, p>.05] alt ölçeklerinden aldıkları puanlar arasında ise cinsiyetlerine göre istatistiksel olarak anlamlı bir farklılık göstermediği bulgusuna ulaşılmıştır.

\section{Öğrencilerin proaktif başa çıkma becerileri algılanan sos-} yo-ekonomik durumlarına göre incelenmesi

Öğrencilerin proaktif, reaktif, stratejik plânlama, aracı duygusal destek, önleyici ve kaçınma başa çıkma becerilerinin algılanan sosyo-ekonomik durumuna göre karşılaştırmak için gerekli varsayımların karşılandığı doğrulandıktan sonra tek yönlü varyans analizi yapılmış ve sonuçlar aşağıda Tablo 9'da verilmiştir. Reaktif ve stratejik plânlama başa çıkma becerilerinde ise gruplara âit varyanslar homojen dağılmadığı için bireylerin bu başa çıkma becerine âit puan ortalamaları ile sosyo-ekonomik durumları tek yönlü varyans analizinin parametrik olmayan teknikleri içerisindeki karşılığı olan Kruskal Wallis H testi ile test edilmiştir. Tek yönlü varyans analizine âit sonuçlar Tablo 10 'da Kruskal Wallis H testine âit sonuçlar ise Tablo 9'da verilmiştir. 
Tablo 9. Öğrencilerin Proaktif, Önleyici, Aracı Duygusal Destek ve Kaçınma Başa Çıkma Becerilerinin Sosyo-ekonomik Durumlarına Göre Anova Testi Sonuçları

\begin{tabular}{|c|c|c|c|c|c|c|c|c|}
\hline $\begin{array}{l}\text { Proaktif Başa } \\
\text { Çıkma Becerileri }\end{array}$ & $\begin{array}{l}\text { Algilanan Gelir } \\
\text { Durumu }\end{array}$ & $\mathbf{N}$ & $\bar{X}$ & ss & Sd & $\mathbf{F}$ & $p$ & $\begin{array}{c}\text { Anlamlı } \\
\text { Fark }\end{array}$ \\
\hline \multirow{5}{*}{$\begin{array}{l}\text { Proaktif } \\
\text { Başa Çıkma }\end{array}$} & 750 TL ve alt1 & 90 & 29.25 & 3.75 & & \multirow{5}{*}{1.17} & \multirow{5}{*}{0.32} & \multirow{5}{*}{---- } \\
\hline & 751-1500TL & 198 & 28.58 & 3.62 & & & & \\
\hline & 1501-2250TL & 75 & 28.20 & 3.76 & $\begin{array}{c}4 \\
417\end{array}$ & & & \\
\hline & $2251-3000 \mathrm{TL}$ & 30 & 28.65 & 3.33 & & & & \\
\hline & 3000TL ve üstü & 30 & 28.45 & 3.33 & & & & \\
\hline \multirow{5}{*}{$\begin{array}{l}\text { Önleyici Başa } \\
\text { Çıkma }\end{array}$} & 750 TL ve altı & 90 & 15.73 & 2.25 & \multirow{5}{*}{$\begin{array}{c}4 \\
417\end{array}$} & \multirow{5}{*}{2.23} & \multirow{5}{*}{0.08} & \multirow{5}{*}{---- } \\
\hline & 751-1500TL & 198 & 15.87 & 2.34 & & & & \\
\hline & 1501-2250TL & 75 & 15.20 & 2.58 & & & & \\
\hline & $2251-3000 \mathrm{TL}$ & 30 & 16.29 & 2.37 & & & & \\
\hline & 3000TL ve üstü & 30 & 15.13 & 2.25 & & & & \\
\hline \multirow{5}{*}{$\begin{array}{l}\text { Aracı } \\
\text { Duygusal } \\
\text { Destek }\end{array}$} & 750 TL ve alt1 & 90 & 39.45 & 5.69 & \multirow{5}{*}{$\begin{array}{c}4 \\
417\end{array}$} & \multirow{5}{*}{0.56} & \multirow{5}{*}{0.64} & \multirow{5}{*}{---- } \\
\hline & 751-1500TL & 198 & 38.59 & 5.59 & & & & \\
\hline & 1501-2250TL & 76 & 38.27 & 6.22 & & & & \\
\hline & $2251-3000 \mathrm{TL}$ & 30 & 38.88 & 6.05 & & & & \\
\hline & 3000TL ve üstü & 30 & 38.76 & 5.49 & & & & \\
\hline \multirow{5}{*}{$\begin{array}{l}\text { Kaçınma Başa } \\
\text { Çıkma }\end{array}$} & 750 TL ve alt 1 & 90 & 7.52 & 1.97 & \multirow{5}{*}{$\begin{array}{c}4 \\
417\end{array}$} & \multirow{5}{*}{0.23} & \multirow{5}{*}{0.87} & \multirow{5}{*}{---- } \\
\hline & 751-1500TL & 198 & 7.33 & 2.09 & & & & \\
\hline & $1501-2250 \mathrm{TL}$ & 75 & 7.28 & 2.16 & & & & \\
\hline & 2251-3000TL & 30 & 7.29 & 2.32 & & & & \\
\hline & 3000TL ve üstü & 30 & 7.56 & 2.09 & & & & \\
\hline
\end{tabular}

Varyans analizi tablosuna bakıldığında ise, öğrencilerin dört proaktif başa çıkma becerisinde de algılanan sosyo-ekonomik durumlarına göre istatistiksel olarak anlamlı bir farklılık görülmediği test edilmiştir. Bu analiz sonucunda, öğrencilerin proaktif, önleyici, aracı duygusal destek ve kaçınma başa çıkma becerileri üzerinde sosyo-ekonomik durumlarının anlamlı bir etki yapmadığı yorumu yapılabilir. 
Tablo 10. Öğrencilerin Reaktif ve Stratejik Planlama Başa Çıkma Becerinin Algilanan Sosyo-ekonomik Durumlarına Göre Kruskal Wallis H Testi Sonuçları

\begin{tabular}{lcccccc}
\hline $\begin{array}{l}\text { Proaktif Başa } \\
\text { Çıkma } \\
\text { Becerileri }\end{array}$ & $\begin{array}{c}\text { Algılanan Gelir } \\
\text { Durumu }\end{array}$ & N & $\begin{array}{c}\text { Sıra } \\
\text { Ort. }\end{array}$ & Sd & $\mathbf{X}^{\mathbf{2}}$ & $\boldsymbol{p}$ \\
\hline Reaktif & 750TL ve altı & 90 & 191.30 & 4 & 3.863 & .277 \\
Başa Çıkma & 751-1500TL & 198 & 204.10 & 417 & & \\
& 1501-2250TL & 75 & 203.64 & & & \\
& 2251-3000TL & 30 & 233.89 & & & \\
& 3000TL ve Üstü & 30 & 211.09 & & & \\
& & & & & & \\
& 750TL ve altı & 90 & 211.95 & 4 & 4.207 & .240 \\
Planlamik & 751-1500TL & 198 & 203.32 & 417 & & \\
& 1501-2250TL & 75 & 184.71 & & & \\
& 2251-3000TL & 30 & 228.06 & & & \\
& 3000TL ve Üstü & 30 & 220.08 & & & \\
\hline
\end{tabular}

Öğrencilerin reaktif ve stratejik plânlama başa çıkma becerilerinin algılanan sosyo-ekonomik durumlarına göre karşılaştırıldığı Tablo 10'daki veriler incelendiğinde, her iki başa çıkma becerisinin puan ortalamaları algılanan sosyo-ekonomik durumlarına göre istatistiksel olarak anlamlı bir farklılık göstermediği bulgusuna ulaşılmıştır.

\section{Sonuç ve Tartışma}

$\mathrm{Bu}$ araştırma kapsamında ergenlerde özerkliğin yordayıcısı olarak bağlanma stilleri ve proaktif kişilik yapısı incelenmiştir. Ayrıca öğrencilerin özerklik, bağlanma stilleri ve proaktif kişilik yapısı; cinsiyet, algılanan sosyo-ekonomik duruma göre farklılaşma gösterip göstermediği ile ilgili sorulara cevap aranmıştır. 
Yapılan regresyon analizi sonucuna göre; araştırmanın "Ergenlerde bağlanma stilleri ve proaktif kişilik yapısı özerkliğin yordayıcısı mıdır?" kritik sorusunu test etmek için çoklu regresyon analizi yapılmıştır. Öğrencilerin bağlanma stilleri ve proaktif kişilik yapıları, özerklik gelişimlerinin anlamlı birer yordayıcısı olarak tespit edilmiştir. Ayrıca proaktif başa çıkma envanteri ölçeğinin alt boyutlarından olan proaktif başa çıkma ve bağlanma stilleri alt boyutlarından olan güvenli bağlanmanın özerkliğin anlamlı birer yordayıcısı olduğu bulgusuna ulaşılmıştır. Bağlanma stilleri alt boyutlarından olan saplantılı bağlanma ve proaktif başa çıkma envanteri alt boyutu olan kaçınma başa çıkma ise analize üçüncü ve dördüncü sıradan girerek özerkliğin birer yordayıcı olarak da tespit edilmiştir.

Özerkliğin yordanmasına ilişkin regresyon katsayılarına bakıldığında ise proaktif başa çıkma boyutu ile güvenli bağlanma boyutu arasında pozitif yönlü bir ilişkinin; kaçınma başa çıkma boyutu ile saplantılı bağlanma boyutu arasında ise negatif yönlü bir ilişkinin olduğu bulunmuştur. Ayrıca özerkliğin güvenli bağlanma ve proaktif başa çıkma boyutları ile açıklanıyor olması ve ikisi arasında pozitif yönlü bir ilişkinin varlığı araştırmamızda beklenen bir sonuçtur. Çünkü bireyin doğduğunda annesiyle kurduğu iletişim önceleri sadece çocuğun biyolojik varlığının devamına hizmet ederken daha sonra bu etkileşim biçimi (bağlanma) içselleştirilerek bireyin hayatının bütün yönlerini etkileyen bir etkileşim biçimi hâline gelir (Hamarta, 2004). Bağlanma kuramının temelinde yatan içsel çalışan modelleri bu içselleştirmeyi sağlayan temel mekanizmalardır. Bowlby’ye (1982) göre 
zihinsel temsiller birbirini tamamlar niteliktedir; bakıcılarının ulaşılır, güvenilir ve ilgili olduğuna dâir bir model geliştiren çocuk kendisinin de güvenilmeye, ilgilenilmeye ve sevilmeye değer bir çocuk olduğuna yönelik bir model geliştirir. Tersine, bağlanma figürü çocuğun ihtiyaçlarına tepkisiz kalır ya da uygun olmayan cevaplar verirse çocuk bağlanma figürünü reddedici olarak kendisini de sevilmeye ve desteklenmeye değmez olarak kodlar (Güngör, 2000). Bağlanma ilişkisi bu yönüyle bireyin kişilik gelişimde önemli bir yere sâhiptir. Kabul edici ve destekleyici âilelerin yanında büyüyen çocuklar, sosyal ortamlarda daha katılımcı, kendine özsaygısı olan ve olumlu benlik yapısına sâhip olarak yetişmektedirler.

Ergenlerin anne baba ile bağlanma ilişkisini inceleyen araştırmalar, ergenlik döneminde âilesi ile güvenli bağlanma ilişkisi içinde olan gençlerin arkadaşlık ilişkilerinde daha başarılı olduklarını, sosyal açıdan kendilerini daha yetkin hissettiklerini, daha yüksek düzeyde özsaygılarının olduğunu, fiziksel açıdan daha sağlıklı olduklarını göstermiştir. Erken yaşlarda çocuklarının gereksinimlerini koşulsuz ve tutarlı olarak karşılayan, yakınlık ve sevgisini esirgemeyen, destekleyici âilelerin çocukları güvenli bağlanma geliştirmektedir (Sümer ve Güngör, 1999). Bu açıdan özerklik gelişiminin temelleri ile bağlanma kuramı arasında ilişki bulunmaktadır. Bağlanma kuramcıları keşfetme davranışını özerkliğin ilk belirtisi olarak görürler ve bağlanma, özerklik arasındaki ilişkiye dikkat çekerler (Bowlby, 1982). Bağlanma kuramı ile yapılan kültürlerarası çalışmalar göstermiştir ki duyarlılık ve ilginin güven oluşturmadaki rolü büyüktür ve güvenli bağlanmanın özerkliği 
de kapsayan sosyal yetkinlik üzerindeki olumlu etkisi bulunmaktadır (Posada, Jacobs, Richmond, Carbonell, Alzate, Bustamante ve Quiceno, 2002).

Bağlanmaya göre çocuk ve bakım veren (anne-baba...) arasındaki ilişkinin sıcaklığa, desteğe dayalı nitelikte olması çocukta güvenin, kendine olan inancın gelişmesini sağlamaktadır. Bakım verenin çocuğun ihtiyaçlarına karşı duyarlılığı çocukta anneye karşı güvenli bağlanmayı sağlamakta, güvenli bağlanma da özerkliğin önemli parçası olan çocuğun keşfini desteklemektedir. Çocuklukta başlayan bu keşif ergenlik döneminde de kendini göstermektedir. Bireyin kişilik gelişimine önemli katkı sağlayan özerklik, ergenin bireyselleşme ve ilişkiselliği sürdürme konusunda destekçisi olmaktadır. Noom, Dekovic ve Meeus (1999), bağlanma stilleri ve özerkliğin ergenlik dönemindeki psikolojik kendini ayarlama ilgili araştırmalarında, özerkliğin anne-baba ve akranlara bağlanmayla ilişkili olduğu sonucuna ulaşılmıştır. $\mathrm{Bu}$ durum ise araştırma bulgularımızı destekler nitelikte sonuçlardandir.

Problem çözme, sorumluluk alma, inisiyatif üstlenme gibi beceriler bireyin özerklik gelişimi ile bağlantılıdır; çünkü bireyin problemler karşısında baş etme stratejilerini geliştirmesi kendine olan inancına ve özerk davranışlarına bağlıdır. Fuhrman ve Holmbeck (1995), üniversite eğitimi için âilelerinden ayrılan gençlerle ilgili yaptıkları araştırmada, evden ayrılmalarıyla birlikte öğrencilerin gittikleri yerlerde daha fazla davranışsal özerklik gösterdiklerini ve karar verme sürecinde daha fazla kişisel kontrolleri olduğunu belirtmişlerdir. $\mathrm{Bu}$ 
durum davranışsal özerklik ve proaktif başa çıkma, yani kendi kontrolünü sağlama, sorumluluğu üstlenme gibi davranışlar arasında ilişkinin olduğunu göstermektedir. Ergenlik döneminin belirgin özelliklerinden olan özerklik gelişimi ergenin kişiliğinin şekillenmesi bak1mından önemlidir. Davranışsal özerklik, kişinin hayatında bağımsız kararlar alarak bu kararları uygulama ve aldığı kararlar için gerekli olan plana uyma becerisidir (Steinberg, 2007). Özerklik gelişimi bireyin bireyselleşme yolundaki önemli özelliklerinden biri ve bireyin doğasından kaynaklanan en önemli ihtiyacıdır.

Cinsiyete göre öğrencilerin özerklik gelişimleri, bağlanma stilleri ve proaktif kişilik yapıları karşılaştırılmış olup ve yapılan t testi sonuçlarına göre özerklik gelişimlerinde cinsiyete göre anlamlı farkl1laşmanın olmadığı; ancak bağlanma stillerinde erkek öğrencilerin güvenli ve saplantılı bağlanma puan ortalamalarının yüksek olduğu kız öğrencilerin de korkulu bağlanma puan ortalamasının yüksek olduğu bulgusuna ulaşılmıştır. Proaktif başa çıkma envanterinden elde edilen puanlar açısından kız öğrencilerin proaktif başa çıkma düzeylerinin erkek öğrencilere göre daha yüksek olduğu tespit edilmiştir. Özellikle proaktif, reaktif, stratejik plânlama ve aracı-duygusal destek arayışı puanları açısından kızların erkek öğrencilere göre daha yüksek ortalamaya sâhip oldukları bulgusuna ulaşılmıştır.

Demir (2002), ilköğretim öğrencileri üzerinde yaptığ çalışmasında çocukların özerklik düzeylerinin cinsiyete göre fark göstermediği bulgusuna ulaşmıştır. Bununla birlikte Fleming (2005), ergen özerkliği konusunda cinsiyetler arasındaki farklılığı incelemiştir. Bu çalışmada 
elde edilen sonuçlara göre, özerklik gelişimi cinsiyete bağlı belirgin bir farklılık göstermemiştir. Bu iki araştırmada bulgularımızı destekler niteliktedir. Acar, Arıcıoğlu ve Güntekin'in (2008) araştırma bulgularına göre öğrencilerin bağlanma düzeylerinin cinsiyet açısından anlamlı farklılık göstermediği sonucuna ulaşılmıştır. Buna karşın Kaya (2001), araştırmasında erkekler lehine güvenli bağlanma puanları yüksek bulunmuştur. Sonuç olarak bağlanma stillerinin ve özerklik düzeylerinin cinsiyete göre farklılaştığına dâir alan yazında farklı araştırma sonuçları vardır. Proaktif kişilik yapısı girişimcilikle yakından ilgili bir kavram olarak da nitelendirilirken sosyologlar girişimciliği, sosyolojik olarak temellendirirler ve ortaya çıkmasında çevre, eğitim, yaş, cinsiyet, âile kökeni gibi sosyal faktörleri fazlası ile önemserler (Bridge, Neil ve Cromine, 1998). 29 ülkede yapılan GEM araştırma sonuçlarına göre, girişimcilik üzerinde erkekler lehine dengesiz bir dağılım olduğu; fakat bu verinin ülkelere göre farklılaşma eğilimi gösterdiğidir (TÜSİAD, 2002). Bu sonuç araştırma bulgularımızla cinsiyet değişkeni açısından farklılaşmanın olması konusunda benzerlik göstermektedir; fakat erkekler lehine bir sonucun çıkması ise bulgularımızla çelişir niteliktedir; çünkü bulgularımıza göre proaktif, reaktif, stratejik plânlama ve aracı destek arayışı kız öğrencilerin daha fazla kullandıkları baş etme becerileri olarak tespit edilmiştir. Alanyazındaki Şahin (2006)'in yaptığ 1 araştırmaya göre proaktif başa çıkma envanterinin boyutları arasında yer alan stratejik plânlama, kaçınma başa çıkma ve aracı duygusal destek arayışı cinsiyete göre anlamlı olarak farklılaşmaktadır. Bu araştırma sonuçları da bulgularımızı destekler niteliktedir. 
Algılanan sosyo-ekonomik duruma göre öğrencilerin özerklik, bağlanma stilleri ve proaktif kişilik yapıları karşıllaştırılmış olup özerklik ve proaktif kişilik yapılarında bireyin sosyoekonomik durumuna göre görece olarak alt ve üst sed gelen grupların ortalamaları arasında fark olsa da istatiksel olarak anlamlı bir farklılaşmanın olmadığı sonucuna ulaşılmıştır. Sosyo-ekonomik duruma göre bağlanma stilleri karşılaştırıldığında saplantılı, korkulu ve kaçınma bağlanma stili puanları açısından öğrencilerin puan ortalamaları anlamlı bir farklılık yokken güvenli bağlanma stilinde ekonomik düzey arttıkça öğrencilerin gruplara âit puan ortalamalarının arttığı bulgusuna ulaşılmıştır.

Demir'in (2002), araştırmasında özerklikle sosyo-ekonomik düzey arasında anlamlı bir ilişki olduğunu saptamıştır. Üst sosyo-ekonomik düzeydeki çocukların özerklik düzeylerinin en yüksek grup olduğu, bunu orta sosyo-ekonomik düzeydeki grubun takip ettiği ve alt sosyo-ekonomik düzeyden gelen grubun ise özerklik düzeylerinin en düşük grup olduğu tespit edilmiştir. Bu durum araştırma bulgularımızla çelişmektedir; ancak Kağıtçıbaşı (2007), maddî bağlılık (zorunlu ihtiyaçlar) azaldıkça, çocukların özerklikleri daha fazla desteklenmekte; âilenin refahı için çocuğun maddî katkısının öneminin azalması nedeniyle, artık çocuğun özerkliği bir tehdit olarak algılanmamaktadır. Ancak, duygusal bağımlılıklara hâlâ önem verilmesi nedeni ile çocuğun âilesine yakın ve bağlı olması istenmektedir. Yani âileler, çocuğun özerklik gelişimi desteklenmesine rağmen bağlılığının da devamı sağlanmak eğilimindedirler. $\mathrm{Bu}$ da özerklik gelişiminin âilenin sâhip olduğu maddî güçten ziyâde çocuk yetiştirme tutum, 
davranışları ile ilgili olduğunu göstermektedir. Yine Kağıtçıbaşı'na (2007), göre klasik modernleşme anlayışındaki sosyo-ekonomik gelişmelerle birlikte karşılıklı bağımlı âile modelinden bağımsız âile modeline doğru bir değişme yaşanacağı görüşünü eleştirmiş ve yakın aile bağlarının önemli olduğu kültürlerde kentleşme ve sanayileşmeye karşın yakın bağların sürdüğünü belirtmiştir. Cebeci (2009), araştırmasında bağlanma stilleri ve sosyo-ekonomik düzey arasında bir ilişkiye rastlanmamıştır. Konyalığlu (2000), araştırmasında sosyoekonomik düzeyi yüksek öğrenciler güvenli bağlanma stilinin özelliklerini daha fazla taşıyan gruplarken, orta gelirli öğrenciler ise bu özelliği en az olan grup olarak görülmüştür. Düşük gelirli öğrencilerin ise kaygı1lı bağlanan grup olduğu bulunmuştur. Bu sonuç, araştırma sonuçlarımızı destekler niteliktedir. Diyebiliriz ki bağlanma doğumdan önce başlayan bir süreçtir. Bebeğin anne karnındayken annesinin sesini tanıması ve ona tepki vermesi, doğum sonrasında ise ihtiyaçları karşılandıkça anne ile kuvvetli bağın kurulması sürecidir ve bu bağ zaman içinde genişleyerek diğer sosyo-demografik ögelerle ilişki içinde olmaktadır. Şahin (2006), araştırmasında bireyin sosyo-ekonomik düzeyi ile proaktif kişilik yapısı arasında bir ilişkiye rastlanmamıştır. Bu sonuç araştırma bulgularımızı destekler niteliktedir. Proaktif kişilik yapısı sonradan kazanılan ve bireyin içinde bulunduğu çevreyi etkileme isteği ile ortaya çıkan psikolojik ve sosyolojik bir durumdur. Ayrıca Covey (1998), proaktif olmayı; "koşullara, duygulara dayanan tepkiler yerine değerlere ve prensiplere dayanan davranış yeterliliğine sâhip olmak" şeklinde ifade ederken bireyin davranışlarını şekillendiren koşullar değil, kendi öngörüleridir. 


\section{Öneriler}

$\mathrm{Bu}$ araştırma lise öğrencilerine yönelik yapılmıştır. Araştırma sonucu analizler incelendiğinde; bağlanma stilleri ve proaktif kişilik yapısı özerkliğin yordayıcıları olarak tespit edilmiştir. Bu nedenle okul rehberlik servislerince hazırlanan programlarda ve danışmanlık hizmetlerinde proaktif kişiliği ve âile içi ilişkiselliği ön plâna çıkaran etkinliklerin olmasının ergenlikte özerklik gelişimini destekleyeceği düşünülmektedir.

Türkiye'de genç nüfusun toplam nüfusa oranının yüksek olduğu göz önünde bulundurulduğunda bu araştırmanın sonuçları önemli hâle gelmektedir. Özellikle ergenlik döneminde yaşanan âile içi çatışmalar, madde bağımlılığı, cinsel istismar, fiziksel-psikolojik şiddet gibi konularda ergenin ruh sağlığını etkileyen ve onu dayanıklı yapan en önemli özellik şüphesiz güçlü bir kişilik yapısıdır. Olumsuz hayat olayları karşısında bireyin daha güçlü bir kişilik gelişimi sergilemesi için araştırmanın sonuçları değerlendirildiğinde güvenli bağlanma ile proaktif başa çıkma becerileri arasında anlamlı ilişkinin olması ve her ikisinin de özerkliği yordadığının tespit edilmiş olması önemlidir. $\mathrm{Bu}$ nedenle bebeklikten itibaren bireyin keşfi ve toplumsallığ üstelenen, proaktif beceri repertuarını geliştirecek eğitim ortamlarının oluşturulması onun özerklik gelişimini destekleyecektir.

Araştırma sonucu analizler incelendiğinde bağlanma stilleri ve proaktif kişilik yapısı arasında pozitif yönlü bir ilişkinin olduğu saptanmıştır. Güvenli bağlanma stili gösteren öğrencilerin proaktif başa çıkma becerilerini kullandıkları bulgusundan yola çıkarak; bireyin 
bebeklik döneminde ihtiyaçlarının giderilmesi ve ona güvenli bir ilişki ortamı sunan âile içerisinde yetişmesi ergenlik döneminde bireyin çeşitli olumsuz hayat olayları karşısında başa etme stratejilerini kullanmasını, yani proaktif kişilik özelliği geliştirmesini sağlayacaktır. $\mathrm{Bu}$ nedenle gerek öğretmenlere gerekse velilere yönelik öğrencilerin proaktif kişilik yapısı gelişiminin destekleyici eğitim programlarının uygulanması önerilmektedir.

Yapılacak boylamsal (zamansal) nitelikli araştırmalar kişilik gelişiminin önemli bileşenleri olan bağlanma, özerklik gelişimi ve proaktif kişilik yapıları gibi kavramların daha iyi anlaşılabilmesi sağlayabilir.

$\mathrm{Bu}$ araştırmada proaktif başa çıkma becerisi özerkliğin anlamlı bir yordayıcısı olarak saplanmıştır. Proaktif başa çıkma; sorumluluk alma, çevresini etkileme ve değişimi başlatma gibi girişimcilik kavramlarını kapsayan bir kişilik yapısıdır. Bu özelliğe sâhip bireyler özerkliklerine düşkün olmakla birlikte; kaçınma başa çıkma becerisine sâhip bireylerin de özerklik gelişimlerinin desteklendiği sonucuna ulaşılmıştır. $\mathrm{Bu}$ nedenle proaktif kişilik yapısı ile özerklik gelişimi arasındaki ilişkinin incelendiği kapsamlı karma çalışmaların yapılması uygun olacaktır.

Araştırmada, saplantılı bağlanma stili ile kaçınma başa çıkma arasında negatif yönlü bir ilişki saptanmıştır. Bu beklenen bir sonuç değildir; çünkü saplantılı bağlanma stiline sâhip bireyler olumsuz benlik modeline sâhip olmakla birlikte kendilerinin sevilmeye değer bir 
birey olmadıklarına inanırlar ve başkalarını sevilmeye değer olarak görürler. Kaçınmacı başa çıkma becerisini geliştiren bireyler ise sorunu görmezden gelirler, olaylar ve durumlar karşısında kaçma eğilimi gösterirler ve kendilerine karşı güvenleri yoktur. Bu nedenle bu konuda farklı örneklem gurupları üzerinde araştırmalar yapılması uygun olacaktır.

\section{Kaynakça}

Acar, N. V., Arıcıoğlu, A. ve Güntekin, F. (2008). Üniversite öğrencilerinin güvengenlik düzeyinin incelenmesi. Hacettepe Üniversitesi Eğitim Fakültesi Dergisi (H. U. Journal of Education), 35, 342-350.

Bartholomew, K. ve Horowitz, L. M. (1991). Attachment styles among young adults:atest of a four-category model. Journal of Personality and Social Psychology. 61(2), 226-244.

Bateman, T. S. ve Crant, M. J. (1993). The proactive component of organizational behavior: a measure and correlates. Journal of Organizational Behavior, 14, 103-118.

Bridge, S., Neil, K. O. ve Cromine, S. (1998). Understanding enterprise, entrepreneurship and small business. London: Macmillan Business.

Bowlby, J. (1982). Attachment and loss: Attachment (2. bask1). New York: Basic Books.

Bowers, K. S. (1973). Situationism in psychology: an analysis and critique. Psychological Bulletin, 80(5), 307-336.

Büyüköztürk, Ş. (2011). Sosyal bilimler için veri analizi el kitabı. Ankara: Pegem Yayıncılık. 
Cebeci, C. S. (2009). Tam aileye ve tek ebeveyne sahip aileden gelen 7-12 yaşları arasındaki çocukların bağlanma stilleri ve kaygı durumları arasındaki ilişki. Yayımlanmamış yüksek lisans tezi, Maltepe Üniversitesi, Sosyal Bilimler Enstitüsü.

Covey, R. S. (1998). Önemli işlere öncelik. (O. Deniztekin, Çev.). İstanbul: Varlık Yayınları. (Orijinal çalışma basım tarihi 1998)

Deci, E. L. ve Ryan R. M. (2000). The "what" and "why" of goal pursuits: human needs and the self-determination of behavior. Psychol Inq, 11(4), 227-268.

Demir, T. Ş. (2002). I Ilköğretim ögrrencilerinin kültürel ekinlikleri ile özerklikleri arasındaki ilişski. Yayımlanmamış doktora tezi, Ankara Üniversitesi, Sosyal Bilimler Enstitüsü.

Fleming, M. (2005). Gender in adolescent autonomy: distinction between boys and girls accelerates at 16 years of age. Electronic Journal of Research in Education Psychology. 3(2), 33-52.

Fuhrman T. ve Holmbeck, G. N. (1995). A contextual-moderator analyses of emotional autonomy and adjustment in adolescence. Child Development, 66, 793-811.

Greenglass, E. R., Schwarzer, R., Jakubiec, D., Fiksenbaum, L. ve Taubert, S. (Temmuz, 1999). The proactive coping inventory (PCI): a multidimensional research instrument. 20. Uluslararas1 stres ve anksiyete araştırmaları topluluğu konferansında sunulan bildiri, Cracow, Poland.

Grotevant, H. D. ve Cooper, C. R. (1985). Patterns of interaction in family relationships and the development of identity exploration in adolescence. Child Development, 56(2), 415-428.

Güngör, D. (2000). Bağlanma stillerinin ve zihinsel modellerin kuşaklararası aktarımında ana babalık stillerinin rol. Yayımlan- 
mamış doktora tezi. Ankara Üniversitesi, Sosyal Bilimler Enstitüsü.

Hamarta, E. (2004). Bağlanma teorisi. Anadolu Üniversitesi Ĕ̆itim Fakültesi Dergisi, 14(1), 53-66.

Kağıtçıbaşı, Ç. (2007). Family, self, and human development across cultures, theory and applications (2. bask1.). Londra: Lawrence Erlbaum Associates.

Kaya, K. (2001). Meslek lisesi öğrencilerinin atılganlık ve sürekli kaygı düzeylerinin karşılaştırılması üzerine bir araştırma. Yayımlanmamış yüksek lisans tezi, Dokuz Eylül Üniversitesi.

Konyalığlu, P. (2000). Üniversite öğrencilerinin duygusal ilişki bă̆lanma tarzları ile kişilik tipleri arasındaki ilişkinin incelenmesi. Yayımlanmamış yüksek lisans tezi, Marmara Üniversitesi, Eğitim Bilimleri Enstitüsü.

Musaağaoğlu, C. (2004). Ergenlik sürecinde özerkliğin gelişimi ile algılanan ana-baba tutumları arasındaki ilişkiler. Yayımlanmamış yüksek lisans tezi, Hacettepe Üniversitesi, Sosyal Bilimler Enstitüsü.

Noom M. (1999). Adolescent autonomy: characteristic and correlates. Delft: Eburon.

Noom, M. J., Dekovic, M. ve Meeus, W. (1999). Autonomy, attachment and psychosocial adjustment during adolescence: a double-edged sword. Journal of Adolescence, 22(6), 771-783.

Noom, M. J., Dekovic, M. ve Meeus, W. (2001). Conceptual analysis and measurement of adolescent autonomy. Journal of Youth and Adolescence, 30(5), 577, 595

Posada, G., Jacobs, A., Richmond, M., Carbonell, O. A., Alzate, G., Bustamante, M. R. ve Quiceno, J. (2002). Maternal caregiving 
and infant security in two cultures. Developmental Psychology, 38(1), 67-78.

Sessa, F. M. ve Steinberg, L. (1991). Family structure and the development of autonomy during adolescence. Journal of Early Adolescence, 11, 38-55.

Steinberg, L. (2002). Adolescence (6. bask1). New York: McGraw Hill.

Steinberg, L. (2007). Ergenlik. (A. Alpay, C. Satman, E. G. Kapçı, E. Uçar ve H. Ercan, Çev.). Ankara: İmge Kitabevi. (Orjinal çalışma basım tarihi 2005).

Sümer, N. ve Güngör, D. (1999). Çocuk yetiştirme stillerinin bağlanma stilleri, benlik değerlendirmeleri ve yakın ilişkiler üzerindeki etkisi. Türk Psikoloji Dergisi, 14(44), 35-58.

Şahin, R. G. (2006). Bireylerin proaktif kişilik yapısı ile benlik saygısı düzeyleri arasındaki ilişkinin incelenmesi. Yayımlanmamış yüksek lisans tezi, Sakarya Üniversitesi, Eğitim Bilimleri Enstitüsü.

Türk Dil Kurumu (2005). Türkçe sözlük. Ankara: Türk Dil Kurumu Yayınları.

TÜSİAD (2002). Türkiye'de girişimcilik. Ankara: TÜSİAD Yayınları.

Zimmer-Gembeck, M. J. ve Collins, W. A. (2003). Autonomy development during adolescence. G. R. Adams ve M. Berzonsky, (Eds.), Handbook of Adolescence içinde (175-204). Oxford: Blackwell. 